\title{
KEADILAN DI JALAN RAYA
}

\author{
Abid Zamzami \\ Fakultas Hukum Universitas Islam Malang \\ Jl. MT. Haryono 193 Malang 65144, Telp 0341 - 551932, 551822, Fax.: 0341 - 552249 \\ Email: abid_zamzami@unisma.ac.id
}

\begin{abstract}
Accessing public road is the right of every citizen since they have to pay taxes for motor vehicle which is principally allocated for road maintenance. Even though all citizens have right to use public road facilities, there are some particular groups of people that are prioritized and always guarded by police guards or using voorijder. The regulation about road users that have primary right to be prioritized in using public road is regulated in Traffic and Commodity Transportation Act No.22/2009 Article 134. However, voorijder is often misused by elites or public figures within social service reasoning so that justice in using public road is not well implemented.
\end{abstract}

Keywords: Voorijder, Law Objectives, Justice

ABSTRAK
Menggunakan jalan raya merupakan hak semua warga negara karena semua warga negara pasti sudah membayar pajak kendaraan bermotor, yang mana pajak tersebut digunakan untuk perawatan jalan raya. Meskipun semua warga berhak menggunakan fasiltas jalan raya ada golongan-golongan tertentu yang harus diprioritaskan dan harus menggunakan pengawalan dari kepolisian menggunakan voorijder. Pengguna jalan yang memperoleh hak utama untuk didahulukan diatur dalam pasal 134 UU No 22 Tahun 2009 tentang Lalu Lintas dan Angkutan Jalan. Namun pada kenyataannya penggunaan voorijder banyak disalahgunakan oleh orangorang kaya dengan alih-alih mengadakan bakti sosial sehingga keadilan dalam menggunakan jalan raya tidak terlaksana dengan baik.

Kata Kunci: Voorijder, Tujuan Hukum, Keadilan

\section{PENDAHULUAN}

Masih ingatkah kita dengan Elanto Wijoyono, nama tersebut mulai dikenal masyarakat berkat aksinya menghadang pengendara (Moge) di simpang empat ringroad Condangcatur Yogyakarta. Dia mengaku aksi ini dilakukannya atas inisiatifnya sendiri, dimana dia geram banyaknya pengendara moge yang mememuhi Kota Yogyakarta tanpa mengindahkan aturan lalu lintas. Mereka seenaknya menerobos lampu lalu lintas yang bisa membahayakan pengguna jalan yang lain. Menurut Elanto saat ini fungsi patwal atau voorijder yang biasanya digunakan untuk urusan resmi sudah mulai dilanggar, hal itu terlihat adanya patwal yang digunakan untuk urusan yang dinilainya tak penting

Aksi Elanto ini mungkin adalah ungkapan hatinya bagaimana dia melihat ketidakadilan yang terjadi di jalan raya. Mungkin saja banyak orang yang mengalami hal yang sama seperti yang dialami Elanto, namun mereka tidak berani bertindak seperti yang dilakukan Elanto. 
Seringkali kita jumpai, kendaraan patroli yang bertugas melakukan pengawalan beserta rombongan kendaraan tertentu yang dikawalnya melintas di jalan raya yang padat. Mobil polisi tersebut (voorijder), membunyikan sirine untuk meminta pengguna jalan lain memberi jalan terhadap rombongan tersebut. Sebagai orang awam, saya beranggapan bahwa yang dikawalnya tersebut adalah orang penting, atau paling tidak setingkat gubernur atau menteri.

Tetapi di lain waktu ada hal yang sedikit janggal sekaligus mengherankan, yaitu kendaraan patroli polisi itu dipergunakan untuk mengawal kendaraan kendaraan mewah (baik roda empat atau roda dua) berplat hitam. Atau juga pengawalan yang dilakukan oleh orang sipil tetapi dengan menyalakan sirine, ${ }^{1}$ yang mana pengawalan ini sering merebut hak jalan kendaraan lain. Dengan melihat fenomena tersebut masih adakah keadilan di jalan raya ini, padahal semua warga negara yang mempunyai kendaraan bermotor baik roda dua atau empat pasti sudah membayar pajak kendaraan bermotor, dengan membayar pajak tersebut maka semua warga negara berhak untuk menikmati jalan raya. Fokus Pembahasan ini adalah dasar hukum penggunaan voorijder di Indonesia dan apakah sudah adil dalam penerapannya di Indonesia.

\section{PEMBAHASAN}

Sebagai warga negara, kita punya hak yang sama di manapun berada termasuk di jalan raya. Hak tersebut dapat berupa hak memakai jalan raya, hak merasa aman di jalan raya, dan hak merasa nyaman di jalan raya. Keamanan yang berkaitan dengan lalu lintas adalah keamanan terhadap manusia, kendaraan, jalan maupun lingkungan. Namun tak jarang hak tersebut terampas manakala ada oknum yang tidak bertanggung jawab merampas hak tersebut, yang saya sebut sebagai oknum di sini tentu beragam, ada si kaya yang bermobil mewah, kumpulan komunitas komunitas bergengsi, atau bahkan sampai remaja usia tanggung yang sering tidak mengindahkan keselamatan berkendara di jalan raya dengan menggunakan pengawalan voorijder. $^{2}$

Terkadang perjalanan kita dihambat atau diberhentikan apabila ada iringan-iringan yang dikawal oleh voorijder tersebut akan melintas, bahkan dalam keadaan macet pun terkadang para iringan ini masih memaksa untuk mendapatkan jalan dan melaju dengan kecepatan tinggi. Terlihat bahwa

\footnotetext{
1 (2010, Juli 9). Pengawalan Kendaraan oleh Polisi Siapa Saja yang Berhak. Diakses pada tanggalJanuari20,2017.Nomed: https://noem3d.wordpress.com/2009/06/11/pengawalan-kendaraan-oleh-polisisiapa-saja-yang-berhak.

2 CR, Miftah. (2014, Januari 11). Hak dan Kewajiban Warga Negara dalam Berlalu Lintas. Diakses pada Januari 16, 2017. Miftah C.R: http://learnmcr.blogspot.co.id/2014/01/hak-dan-kewajiban-warga-negara-lili
} 
adanya sikap arogansi dari iring-iringan tersebut yang juga akan mengancam nyawa pengendara lain. Dengan melihat sikap dari voorijder dan pengendara yang diiringi tersebut apakah salah atau benar. Salah atau kesalahan adalah perbuatan yang bertentangan dengan atau melanggar ketentuan mengenai hak dan keadilan yang mana kesalahan itu terdiri dari salah di sisi moral (etik) dan salah menurut hukum. ${ }^{3}$

Salah di sisi moral atau lazim disebut kesalahan alamiah (natural wrong) adalah perbuatan yang secara moral atau alamiah adalah salah, yaitu perbuatan yang dianggap bertentangan dengan hukum (keadilan) alam. Sedangkan salah dari sisi hukum adalah perbuatan yang dinilai salah oleh pihak yang berwenang, yaitu yang ditentukan oleh peraturan perundangundangan yang berlaku. ${ }^{4}$

Kemudian dengan melihat sikap voorijder dan kendaraan yang diiringinya, kita sebagai warga apakah masih mempunyai hak untuk menggunakan jalan raya. Hak dapat dibagi menjadi hak bersifat moral dan hukum. Hak dari segi moral merupakan suatu kepentingan yang diakui dan diatur oleh suatu ketentuan moral sehingga suatu kepentingan yang melanggar terhadapnya akan dikatakan sebagai kesalahan dari segi moral. Hak dari segi hukum merupakan kepentingan yang diakui dan dilindungi oleh suatu peraturan perundang-undangan yang pelanggaran terhadapnya akan merupakan kesalahan dari segi hukum.

Hak menurut K. Bartens adalah merupakan klaim yang dibuat oleh orang atau kelompok yang satu terhadap yang lain atau terhadap masyarakat. Orang yang mempunyai hak bisa menuntut (dan bukan saja mengharapkan atau menganjurkan) bahwa orang lain untuk menghormati hak itu, namun dalam hal ini yang amat penting yaitu hak adalah klaim yang sah atau klaim yang dapat dibenarkan, sebab mengatakan klaim saja tidak lah cukup. ${ }^{5}$

Hampir setiap orang pasti mengetahui dan menyakini bahwa di dalam dirinya melekat adanya hukum dalam arti hak untuk melakukan dan berbuat sesuatu. Hak merupakan hukum dalam arti sempit, sebab sebagai imbalannya akan terlihat kewajiban dari para subjek hukum itu. Jika berbicara hukum dan hak tidak lepas dari kewajiban, karena keduanya merupakan masalah yang tidak dapat dipisahkan. Dari segi pengertian hukum dan hak dapat dibedakan bahwa hukum atau hukum objektif adalah segala ketentuan yang mengatur hubungan antara orang-orang di masyarakat, sedangkan hak atau hukum ialah sesuatu yang menjadikan

\footnotetext{
${ }^{3}$ Rasjidi, Lili dan Rasjidi, Ira. Thania. (2012). Pengantar Filsafat Hukum. Bandung: Mandar Maju. Hlm. 115

${ }^{4}$ Ibid, Hlm. 116

${ }^{5}$ Erwin, Muhammad. (2011). Filsafat Hukum Refleksi Kritis Terhadap Hukum. Jakarta: Sinar Grafika. Hlm. 239
} 
tuntutan seseorang sesuai menurut ketentuan hukum objektif. ${ }^{6}$

Mengenai unsur yang terdapat pada hak (subjektif recht) itu terdapat beberapa pendapat, yaitu

1. Teori kehendak (B. Winsheid) mengemukan bahwa secara primer ada unsur kehendak. Ia mengemukakan pendapatnya tentang hak, ialah suatu kehendak yang melengkapi dengan kekuatan (macht) yang diberikan oleh tata hukum.

2. Teori kepentingan (Rudolf van Jhering) mengemukakan bahwa dalam hak itu yang penting ialah unsur kepentingan. Ia mengemukakan, bahwa hak ialah kepentingan yang dilindungi oleh hukum

3. Teori kekuatan (macht) oleh Apeldoorn, menurut dia hak itu ialah suatu kekuatan (macht), diatur oleh hukum yang berdasarkan kesusilaan dan fisik. Contohnya, seorang pencuri menguasai barang curian, tetapi tidak mempunyai hak apapun atas barnag itu, karena tidak mempunyai kekuatan dari kesusilaan dan keadilan
4. Lemaire menganggap hak, izin bagi yang bersangkutan untuk berbuat sesuatu. Izin yang diberikan itu bukan dari hukum kepada yang bersangkutan, tapi merupakan hal yang berdiri sendiri. ${ }^{7}$

Disamping itu juga kita coba berbicara terkait dengan pembatasan hak oleh hukum, suatu hak dapat saja menemui pembatasan karena terjadinya konflik antara hak dengan hak yang lain. ${ }^{8}$ Contohnya, seorang pasien psikiatris yang berbahaya bagi masyarakat sekitarnya dapat saja dipaksa untuk dirawat inap di rumah sakit jiwa, sekalipun ia sendiri tidak mau. Tentu saja, orang ini tidak bersalah dan mempunyai hak seperti semua orang lain. Tapi haknya atas kebebasan dalam hal ini dapat dikalahkan, karena orang lain pun mempunyai hak untuk dilindungi terhadap bahaya yang mengancam jiwa mereka. Oleh sebab itu pembatasan adalah hal utama yang mengakibatkan hak-hak kebebasan memang tidak pernah bisa absolut. ${ }^{9}$

Selain hak yang melekat pada diri setiap manusia perlu mengetahui sebaliknya yaitu perbuatan melawan hukum dimana mempunyai hubungan erat dengan perbuatan manusia itu sendiri, boleh dilakukan atau tidak boleh dilakukan.

\footnotetext{
${ }^{6}$ Hay, Marhainis Abdul. (1981). Dasar-dasar Ilmu Hukum. Jakarta: Pradnya Paramita. Hlm. 141

${ }^{7}$ Muchsin. (2006). Ikhtisar Ilmu Hukum Jakarta: Badan Penerbit IBLAM. Hlm. 33

${ }^{8}$ Suseno, Franz Magnis. (1999). Etika Politik (Prinsip-prinsip Moral Dasar Kenegaraan Modern). Jakarta: Gramedia Pustaka Utama. Hlm. 72

${ }^{9}$ Op.Cit, Hlm. 242
} 
Apabila seseorang mengetahui bahwa hal ini merupakan perbuatan melawan hukum, maka yang ada dalam pikirannya adalah mengambil keputusan bahwa hal itu tidak boleh dilakukan. ${ }^{10}$ Perbuatan melawan hukum adalah perbuatan yang tidak boleh dilakukan oleh manusia, karena diketahui bahwa perbuatan melawan hukum itu adalah buruk atau jahat, yang dilakukan oleh manusia. Perbautan melawan hukum adalah perbuatan nuruk, yang dengan alasan apapun tidak boleh dilakukan oleh manusia, tentu saja perbuatan itu ditujukan kepada orang lain, maka dengan demikian perbuatan melawan hukum itu adalah perbuatan keburukan terhadap hak orang lain, yaitu perbuatan yang melanggar hak orang lain. ${ }^{11}$

Pengertian mengenai hukum sebenarnya telah ada pada semua orang, akan tetapi pengertian hukum pada banyak orang tersebut masih sangat kurang, contohnya masih ada yang menyamakan hukum dengan polisi atau apa saja yang tidak boleh dilakukan, itu adalah hukum. Dengan kurangnya pengertian hukum dalam masyarakat maka makna hukum yang luhur tentang hukum menjadi sulit diwujudkan, sebaliknya apabila orang telah memiliki pengetian tentang hukum yang tepat maka akan menaruh hormat terhadap hukum tersebut, kemudian akan timbul semangat untuk menegakkannya, dalam rangka membangun negara hukum yang lebih sempurna. ${ }^{12}$

Hukum dapat dijadikan objek rasa hormat artinya sesungguhnya rasa hormat itu akan timbul ketika mendapat teguram. Karena melanggar suatu peraturan lalu didenda. Kemudian seseorang tersebut setelah didenda atau ditegur akan menyadari bahwa peraturan memang diperlukan, agar kehidupan bersama diatur dengan baik, tetapi kenapa saya telah melanggarnya. Dari peraturan yang ada dapat dipastikan bahwa semua orang akan menikmati ketentraman dan keadilan. Dengan demikian, jelas bahwa jarak antara hukum dan keadilan itu tidak sebegitu jauh, besar kemungkian bahwa orang yang mengerti akan makna hukum yang sesungguhnya pasti akan rela untuk taat pada peraturan tersebut dan kemudian jika penegrtian hukum itu digabungkan dengan keadilan, kemungkinan orang tidak lagi menyamakan hukum dengan sejumlah larangan, melainkan akan menjadikannya sebagai bagian dari cita-cita hidup. ${ }^{13}$

Memahami hukum dapat diketahui melalui pengalaman kita sehari-hari, bahwa

\footnotetext{
10 Muchsin. (2006). Ikhtisar Ilmu Hukum. Jakarta: Badan Penerbit IBLAM. Hlm. 143.

11 Santoso, Agus. (2012). Hukum Moral dan Keadilan. Jakarta: Kencana Prenada Media Group. Hlm. 126

12 Ibid, Hlm. 126

13 Ibid, Hlm. 127
} 
hukum mengatur kehidupan bersama dalam masyarakat, sehingga hukum sebagai gejala sosial, selalu tumbuh dan berkembang mengikuti perkembangan masayrakat atau zaman. Hukum muncul dalam pengalaman pada setiap orang, dan menurut pengalaman itu hukum pertama-tama sebagai kaidahkaidah yang mengatur hidup bersama, bisa perintah dan/atau larangan, ada yang tertulis dan ada yang tidak tertulis. Disamping melalui pengalama sehari-hari bisa melalui studi tentang hukum, bahwa dalam memperoleh suatu pengetahuan yang terperinci tentang peraturan hukum yang berlaku dalam suatu negara, hukum dipahami sebagai peraturan negara yang mengikat. Dalam hal kaitannya dengan keadilan, hukum dipandang sebagai suatu hal yang riil (Undang-Undang dan peraturan lain), bukan merupakan suatu hal yang idiil (keadilan). Maka harus dapat dibedakan antara hukum yang riil dan hukum yang idiil.

Kepastian hukum dimana merupakan ikon untuk hukum modern, maka setiap orang akan melihat fungsi hukum modern sebagai menghasilkan kepastian hukum. Masyarakat, terutama masyarakat modern, sangat membutuhkan adanya kepastian dalam berinteraksi antar para anggotanya dan tugas itu diletakkan di pundak hukum. ${ }^{14}$
Keadilan dapat dimaknai sebagai legalitas. Sesuatu dapat dikatakan adil jika suatu aturan diterapkan pada semua kasus di mana menurut isinya memang aturan tersebut harus diaplikasikan. Adalah tidak adil jika suatu aturan diterapkan pada suatu kasus tetapi tidak pada kasus lain yang sama. Keadilan dalam arti legalitas adalah suatu kualitas yang tidak berhubungan dengan isi tata aturan positif, tetapi dengan pelaksanaannya. $^{15}$ Semua orang mempunyai kemampuan mewujudkan suatu aturan masyarakat yang adil sehingga keadilan itu menjadi fokus tujuan utama pembentukan Undang-Undang. ${ }^{16}$

Berbicara tentang keadilan, yang mana merupakan salah satu tujuan hukum yang paling banyak dibicarakan. Telah disebutkan bahwa tujuan hukum tidak hanya keadilan, tetapi kepastian dan kemanfaatan. Idealnya, hukum memang harus mengakomodasi ketiganya. Misalnya putusan hakim, sedapat mungkin merupakan resultante dari ketiganya. Sekalipun demikian ada yang berpendapat, diantara ketiga tujuan tersebut, keadilan merupakan tujuan paling penting, bahkan ada yang berpendapat keadilan adalah tujuan hukum satu-satunya. Contohnya seperti yang diungkapkan oleh seorang hakim indonesia bisma siregar "bila untuk

\footnotetext{
14 Raharjo, Satjipo. (2006). Hukum Dalam Jagat Ketertiban. Jakarta: UKI Press. Hlm. 133

15 Asshiddiqie, Jimly dan Safaat, Ali. (2012). Teori Hans Kelsen Tentang Hukum. Jakarta: Konpres. Hlm. 21

16 Zainuddin, Ali. (2010). Filsafat Hukum. Jakarta: Sinar Grafika. Hlm. 88
} 
menegakkan keadilan saya korbankan kepastian hukum, akan saya korbankan hukum itu. Hukum hanya sarana, sedangkan tujuannya adalah keadilan. ${ }^{17}$

Aristoteles memberikan sumbangan cukup besar bagi pemikiran tentang hukum dan keadilan, dimana ia menggolongkan keadilan ke dalam keadilan distributif dan keadilan komutatif. ${ }^{18}$ Keadilan distributif yakni keadilan yang memberikan kepada setiap orang jatah menurut jasanya. Artinya keadilan ini tidak menuntut supaya setiap orang mendapat bagian yang sama banyaknya atau bukan persamaannya, melainkan kesebandingan berdasarkan prestasi dan jasa seseorang. Dan keadilan komutatif yakni keadilan yang memberikan kepada setiap orang sama banyaknya, tanpa mengingat jasa-jasa perseorangan, artinya hukum menuntut adanya suatu persamaan dalam memperoleh prestasi atau sesuatu hal tanpa memperhitungkan jasa perseorangan. ${ }^{19}$

Dalam teorinya, Aristoteles juga mengemukakan lima jenis perbuatan yang dapat digolongkan adil. Kelima jenis keadilan yang dikemukakan oleh Aristoteles itu adalah sebagai berikut:

1. Keadilan Komutatif adalah perlakuan terhadap seseorang dengan tidak melihat jasa-jasa yang telah diberikannya.

2. Keadilan Distributif adalah perlakuan terhadap seseorang sesuai dengan jasa-jasa yang telah diberikannya.

3. Keadilan Kodrat Alam adalah memberi sesuatu sesuai dengan yang diberikan oleh orang lain kepada kita.

4. Keadilan Konvensional adalah kondisi jika seorang warga negara telah menaati segala peraturan perundang-undangan yang telah dikeluarkan.

5. Keadilan Perbaikan. Perbuatan adil menurut perbaikan adalah jika seseorang telah berusaha memulihkan nama baik orang lain yang telah tercemar. Misalnya, orang yang tidak bersalah maka nama baiknya harus direhabilitasi. ${ }^{20}$

\begin{tabular}{|c|c|c|c|c|}
\hline No & $\begin{array}{c}\text { Jenis } \\
\text { Keadilan }\end{array}$ & $\begin{array}{c}\text { Maknan } \\
\text { ya }\end{array}$ & Contoh & $\begin{array}{c}\text { Manfa } \\
\text { at }\end{array}$ \\
\hline 1. & Komutatif & $\begin{array}{l}\text { Adalah } \\
\text { perlakuan } \\
\text { terhadap } \\
\text { seseorang } \\
\text { dengan } \\
\text { tidak } \\
\text { melihat } \\
\text { jasa-jasa } \\
\text { yang } \\
\text { dilakukan } \\
\text { nya. }\end{array}$ & $\begin{array}{l}\text { Seorang } \\
\text { Kepala } \\
\text { Daerah } \\
\text { yang } \\
\text { melanggar } \\
\text { hukum } \\
\text { maka akan } \\
\text { dikenakan } \\
\text { sangsi } \\
\text { sesuai } \\
\text { dengan } \\
\text { pelanggar } \\
\text { annya. }\end{array}$ & $\begin{array}{l}\text { Semua } \\
\text { warga } \\
\text { negara } \\
\text { sama di } \\
\text { depan } \\
\text { hukum }\end{array}$ \\
\hline 2. & Distributif & $\begin{array}{l}\text { Adalah } \\
\text { perlakuan } \\
\text { terhadap } \\
\text { seseorang } \\
\text { sesuai } \\
\text { dengan } \\
\text { jasa-jasa } \\
\text { yang telah } \\
\text { dilakukan } \\
\text { nya. }\end{array}$ & $\begin{array}{l}\text { Ali } \\
\text { bekerja } 10 \\
\text { tahun dan } \\
\text { budi } \\
\text { bekerja } 5 \\
\text { tahun. } \\
\text { Pada } \\
\text { waktu } \\
\text { diberikan } \\
\text { hadiah } \\
\text { harus }\end{array}$ & $\begin{array}{l}\text { Mengha } \\
\text { rgai } \\
\text { orang } \\
\text { yang } \\
\text { telah } \\
\text { berjasa } \\
\text { kepada } \\
\text { kita }\end{array}$ \\
\hline
\end{tabular}

17 Tulisan Bersama. (2014). Anotasi Pemikiran Hukum Dalam Perspektif Filsafat Hukum. Malang: UB Press. Hlm. 81

18 Rahardjo, Satjipto. (2000). Ilmu Hukum. Bandung: PT Citra Aditya Bakti. Hlm. 163

19 Mas, Marwan. (2014). Pengantar Ilmu Hukum. Bogor: Ghalia Indonesia. Hlm. 83

20 Ajim, Nanang. Hubungan Hukum, Keadilan, dan Ketertiban. Diakses pada tanggal Maret 6, 2017. Mikirbae: http://www.mikirbae.com/2015/11/hubungan-hukum-keadilan-dan-ketertiban.html. 


\begin{tabular}{|c|c|c|c|c|}
\hline & & & $\begin{array}{l}\text { dibedakan } \\
\text { antara Ali } \\
\text { dan Budi, } \\
\text { yaitu } \\
\text { perbedaan } \\
\text { sesuai } \\
\text { dengan } \\
\text { lamanya } \\
\text { bekerja. }\end{array}$ & \\
\hline 3. & $\begin{array}{l}\text { Kodrat } \\
\text { Alam }\end{array}$ & $\begin{array}{l}\text { Keadilan } \\
\text { kodrat } \\
\text { alam yaitu } \\
\text { memberik } \\
\text { an sesuatu } \\
\text { sesuai } \\
\text { yang } \\
\text { diberikan } \\
\text { orang lain } \\
\text { kepada } \\
\text { kita. }\end{array}$ & $\begin{array}{l}\text { Seseorang } \\
\text { akan } \\
\text { membalas } \\
\text { dengan } \\
\text { kebaikan } \\
\text { apabila } \\
\text { seseorang } \\
\text { tersebut } \\
\text { melakuka } \\
\text { n hal yang } \\
\text { baik pula } \\
\text { kepadanya }\end{array}$ & $\begin{array}{l}\text { Perbuata } \\
\text { n baik } \\
\text { akan } \\
\text { dibalas } \\
\text { dengan } \\
\text { kebaika } \\
\text { n pula }\end{array}$ \\
\hline 4. & Konvesional & $\begin{array}{l}\text { Keadlilan } \\
\text { konvensio } \\
\text { nal yaitu } \\
\text { apabila } \\
\text { seorang } \\
\text { warga } \\
\text { negara } \\
\text { telah } \\
\text { menaati } \\
\text { segala }\end{array}$ & $\begin{array}{l}\text { Ketaatan } \\
\text { warga } \\
\text { negara } \\
\text { dalam } \\
\text { membayar } \\
\text { suatu } \\
\text { pajak }\end{array}$ & $\begin{array}{l}\text { Pemban } \\
\text { gunan } \\
\text { berjalan } \\
\text { dengan } \\
\text { baik }\end{array}$ \\
\hline
\end{tabular}

Keadilan menurut Thomas Aquinas (filsuf hukum alam), membedakan keadilan dalam dua kelompok :

a) Keadilan umum (justitia generalis);

Keadilan umum adalah keadilan menururt kehendak undang-undang, yang harus ditunaikan demi kepentingan umum.

b) Keadilan khusus; Keadilan khusus adalah keadilan atas dasar kesamaan atau proporsionalitas. Keadilan ini debedakan menjadi tiga kelompok yaitu:

I. Keadilan distributif (justitia distributiva) adalah keadilan yang secara proporsional yang

\begin{tabular}{|c|c|c|c|c|}
\hline & & $\begin{array}{l}\text { peraturan } \\
\text { perundang } \\
\text {-undangan } \\
\text { yang telah } \\
\text { diwajibka } \\
\text { n. }\end{array}$ & & \\
\hline 5. & Perbaikan & $\begin{array}{l}\text { Keadilan } \\
\text { menurut } \\
\text { teori } \\
\text { perbaikan. } \\
\text { Perbuatan } \\
\text { adil } \\
\text { menurut } \\
\text { teori } \\
\text { perbaikan } \\
\text { apabila } \\
\text { seseorang } \\
\text { telah } \\
\text { berusaha } \\
\text { memulihk } \\
\text { an nama } \\
\text { baik orang } \\
\text { lain yang } \\
\text { telah } \\
\text { tercemar. }\end{array}$ & $\begin{array}{l}\text { Seseorang } \\
\text { meminta } \\
\text { maaf } \\
\text { melalui } \\
\text { media } \\
\text { masa } \\
\text { karena } \\
\text { telah } \\
\text { mencemar } \\
\text { kan nama } \\
\text { baik orang } \\
\text { lain. }\end{array}$ & $\begin{array}{l}\text { Mengha } \\
\text { rgai } \\
\text { martabat } \\
\text { dan } \\
\text { nama } \\
\text { baik } \\
\text { seseoran } \\
\text { g }\end{array}$ \\
\hline
\end{tabular}

diterapkan dalam lapangan hukum publik secara umum.

II. Keadilan komutatif (justitia cummulativa) adalah keadilan dengan mempersamakan antara prestasi dengan kontraprestasi.

III. Keadilan vindikativ (justitia vindicativa) adalah keadilan dalam hal menjatuhkan hukuman atau ganti kerugian dalam tindak pidana. Seseorang dianggap adil apabila ia dipidana badan atau denda sesuai dengan besarnya hukuman yang telah ditentukan atas tindak pidana yang dilakukannya. ${ }^{21}$

Kemudian apabila melihat dari tujuan keadilan maka terdapat tiga tujuan keadilan yaitu: $^{22}$

21 Huijbers, Theo. (1995). Filsafat Hukum Dalam Lintas Sejarah. Yogyakarta: Kanisius. Hlm. 196

22 Raper, Jan Hendrik. (1991). Politik Hukum Plato. Jakarta: Rajawali. 1991. Hlm. 81 
1. Keadilan sebagai fungsi Keseimbangan.

Adil adalah keadaan yang seimbang. Apabila kita melihat suatu sistem atau himpunan yang memiliki beragam bagian yang dibuat untuk tujuan tertentu, maka mesti ada sejumlah syarat, entah ukuran yang tepat pada setiap bagian dan pola kaitan antar bagian tersebut. Dengan terhimpunnya semua syarat itu, himpunan ini bisa bertahan, memberikan pengaruh yang diharapkan darinya, dan memenuhi tugas yang telah diletakkan untuknya. Setiap masyarakat yang seimbang membutuhkan bermacam-macam aktivitas. Di antaranya adalah aktivitas ekonomi, politik, pendidikan, hukum, dan kebudayaan. Semua aktivitas itu harus didistribusikan di antara anggota masyarakat dan setiap anggota harus dimanfaatkan untuk suatu aktivitas secara proporsional. Keseimbangan sosial mengharuskan kita untuk memerhatikan neraca kebutuhan.

Kajian tentang keadilan dalam pengertian keseimbangan, sebagai lawan ketidakseimbangan, akan muncul jika kita melihat sistem alam sebagai keseluruhan. Sedangkan kajian tentang keadilan dalam pengertian sebagai lawan kezaliman dan yang terjadi ketika kita melihat tiap-tiap individu secara terpisah-pisah adalah pembahasan yang lain lagi. Keadilan dalam pengertian pertama menjadikan kepentingan umum sebagai persoalan. Adapun keadilan dalam pengertian kedua menjadikan hak individu sebagai pokok persoalan. Karenanya, orang yang mengajukan keberatan akan kembali mengatakan, kita tidak menolak prinsip keseimbangan di seluruh alam, tapi pemeliharaan terhadap keseimbangan ini, mau tidak mau, akan mengakibatkan munculnya pengutamaan tanpa dasar. Semua pengutamaan ini, dari sudut pandang keseluruhan dapat diterima dan relevan, tetapi tetap tidak dapat diterima dan tidak relevan dari sudut pandang individual. Keadilan dalam pengertian simetri dan proporsi termasuk dalam konsekuensi sifat Tuhan yang maha bijak dan maha mengetahui.

2. Keadilan dalam Persamaan

Pengertian keadilan yang kedua adalah persamaan dan penafian terhadap diskriminasi dalam bentuk apapun. Ketika dikatakan bahwa seseorang berbuat adil, yang dimaksud adalah bahwa orang itu memandang semua individu secara sama, setara, tanpa melakukan pembedaan dan pengutamaan. Dalam pengertian ini, keadilan sama dengan persamaan. Definisi keadilan seperti itu menuntut penegasan. Kalau yang dimaksud dengan keadilan adalah keniscayaan 
tidak terjaganya beragam kelayakan yang berbeda-beda dan memandang segala sesuatu dan semua orang secara sama rata, keadilan seperti ini identik dengan kezaliman itu sendiri.

Apabila tindakan memberi secara sama rata dipandang sebagai adil, maka tidak memberi kepada semua secara sama rata juga mesti dipandang sebagai adil. Anggapan umum bahwa kezaliman yang dilakukan secara sama rata kepada semua orang adalah keadilan berasal dari pola piker semacam ini. Adapun kalau yang dimaksud dengan keadilan adalah terpeliharanya persamaan pada saat kelayakan memang sama, pengertian itu dapat diterima. Sebab, keadilan meniscayakan dan mengimplikasikan persamaan seperti itu.

3. Keadilan dalam Memberikan Hak.

Pengertian keadilan yang dimaksud ialah pemeliharaan hak-hak individu dan pemberian hak kepada setiap objek yang layak menerimanya. Dalam artian ini, kezaliman adalah pelenyapan dan pelanggaran terhadap hak-hak pihak lain. Pengertian keadilan ini, yaitu keadilan sosial, adalah keadilan yang harus dihormati dalam hukum manusia dan setiap individu benar-benar harus berjuang untuk menegakkannya. Keadilan dalam pengertian ini bersandar pada dua hal, pertama, hak dan prioritas, yaitu adanya berbagai hak dan prioritas sebagai individu bila dibandingkan dengan sebagian lain. Apabila seseorang mengerjakan sesuatu yang membutuhkan hasil, misalnya, ia memiliki prioritas atas buah pekerjaannya. Penyebab timbulnya prioritas dan preferensi itu adalah pekerjaan dan aktivitasnya sendiri. Demikian pula halnya dengan bayi, ketika dilahirkan oleh ibunya, ia memiliki klaim prioritas atas air susu ibunya. Sumber prioritas itu adalah rencana penciptaan dalam bentuk sistem keluarnya air susu ibu untuk bayi tersebut.

Kedua, karakter khas manusia, yang tercipta dalam bentuk yang dengannya manusia menggunakan sejumlah ide atau metode, agar dengan perantaraan ide dan metode, ia bisa mencapai tujuan-tujuannya. Ide-ide itu akan membentuk serangkaian gagasan yang penentuannya bisa dengan perantara. Ringkasnya, agar tiap individu masyarakat bias meraih kebahagiaan yang terpelihara. Pengertian keadilan manusia seperti itu diakui oleh kesadaran semua orang. Sedangkan titiknya yang berseberangan adalah kezaliman yang ditolak oleh kesadaran semua orang. Pengertian keadilan dan kezaliman ini pada satu sisi bersandar pada asas prioritas dan presedensi, dan 
pada sisi lain bersandar pada asaswatak manusia yang terpaksa menggunakan sejumlah konvensi untuk merancang apa yang seharusnya, dan apa yang tidak seharusnya serta mereka-reka baik dan buruk.

Hukum sangat erat kaitannya dengan keadilan, bahkan ada pendapat bahwa hukum harus digabungkan dengan keadilan, supaya benar-benar berarti sebagai hukum, karena memang tujuan hukum itu adalah tercapainya rasa keadilan pada masyarakat. Setiap hukum yang dilaksanakan ada tuntutan untuk keadilan, maka hukum tanpa keadilan akan sia-sia sehingga hukum tidak lagi berharga di hadapan masyarakat, memang sulit menggabungkan keduanya, namun sesulit apapun hal in harus dilakukan demi kewibawaan negara dan peradilan, karena hak-hak dasar hukum itu adalah hak-hak yang diakui oleh peradilan. ${ }^{23}$

Bila adil merupakan unsur konstitutif hukum, suatu peraturan yang tidak adil bukan hanya hukum yang buruk, akan tetapi sematamata bukan hukum : non-hukum. Kalau non hukum, orang tidak terikat akan peraturan yang bersangkutan, dan tindakan balasan tidak sah. Sebaliknya, bila adil merupakan unsur regulatif bagi hukum, suatu peraturan yang tidak adil tetap hukum walaupun buruk, dan tetap berlaku dan mewajibkan (walaupun hanya secara extern berupa sanksi). Maka timbul pertanyaan apakah cukup adanya suatu peraturan dalam bentuk yuridis yang tepat untuk dapat disebut hukum (richtiqes Recht/correct) atau perlu juga peraturan itu sesuai dengan prinsip-prinsip keadilan (gerechtes Recht/just). ${ }^{24}$

Plato mengatakan bahwa manusia itu terdiri dari tiga unsur yaitu pikiran, perasaan dan nafsu. Jika ketiganya dapat berkombinasi dengan baik, maka akan menghasilkan jiwa yang teratur. Hal itu dapat terjadi bila perasaan dan nafsu dikendalikan dan ditundukkan pada akal, dan keadilan terletak dalam batas yang seimbang antara ketiga bagian jiwa tersebut. Manusia menurut plato hanya dapat berkembang melalui negara. Maka keutamaan yang tertinggi oleh manusia adalah ketaatan kepada hukum negara. Segala sesuatu yang ditetapkan oleh undang-undang adalah adil, sebab adil ialah suatu yang bersifat abstrak, dan setiap manusia (warga negara) mempunyai pandangan keadilan yang berbeda, maka negara hadir dengan menyelaraskan keadilan untuk sesama, Dalam mengartikan keadilan, menurut plato bersifat kolektivistik yang memandang keadilan sebagai hubungan harmonis dengan berbagai orgisme sosial. Maka setiap warga negara

23 Lili Rasjidi. (2007). Pengantar Filsafat Hukum. Bandung: Mandar Maju. Hlm. 125

${ }^{24}$ Huijbers, Theo. (__ $)$, Filsafat Hukum. Yogyakarta: Kanisius. Hlm. 48 
harus melakukan tugasnya sesuai dengan posisi dan sifat alamiahnya. ${ }^{25}$

Pasal 3 Undang-Undang No 22 Tahun 2009 tentang Lalu Lintas dan Angkutan Jalan disebutkan bahwa lalu lintas dan angkutan jalan diselenggarakan dengan tujuan salah satunya adalah terwujudnya etika berlalu lintas dan budaya bangsa serta terwujudnya penegakan hukum dan kepastian hukum bagi masyarakat. Disini nampak bahwa kepentingan masyarakatlah yang harus diprioritaskan. Tapi apabila rombongan iringan-iringan yang sering merugikan pengendara lain apabila kita tuduh asosial apakah mereka mau? Maka para pemilik kendaraan mahal ini pasti membantah. Sebab dalam aksinya mereka memang bukan sekadar mengacaukan lalu lintas, tetapi juga (kadang-kadang) membuat aksi sosial seperti bagi sembako kepada rakyat miskin. Artinya, kalau di jalan raya tampak arogan, di tempat gelaran aksi sosial itu mereka adalah orangorang yang berhati lembut.

Orang-orang yang memiliki uang banyak pengguna motor gede atau mobil-mobil yang harganya sangat mahal, betapa pun, bukanlah kelas istimewa di republik ini. Memang sebagian dari mereka adalah pejabat dan pengusaha, tapi tetap tak ada hubungannya antara status sosial itu dengan kegiatan hobi mereka. Silahkan lakukan hobi, apapun itu. Tapi jangan sampai mengganggu orang lain. ${ }^{26}$ Diketahui bahwa kewenangan untuk melaksanakan tugas penegakan hukum dan pengaturan di bidang lalu lintas ada pada Korps Lalu Lintas Kepolisian Republik Indonesia sesuai Pasal 1 angka 3 Peraturan Kepala Kepolisian Negara Republik Indonesia No. 5 Tahun 2012 tentang Registrasi dan Identifikasi Kendaraan

Bermotor

"Korps Lalu Lintas Polri yang
selanjutnya disebut Korlantas Polri
adalah unsur pelaksana tugas pokok
bidang keamanan, keselamatan,
ketertiban, dan kelancaran lalu
lintas yang berada di bawah Kapolri
serta bertugas membina dan
menyelenggarakan fungsi lalu lintas
yang meliputi pendidikan
masyarakat, penegakan hukum,
pengkajian masalah lalu lintas,
registrasidan identifikasi pengemudi
dan kendaraan bermotor serta
patroli jalan raya."

Dalam Pasal 104 ayat 1 Undang-Undang No 22 Tahun 2009 tentang lalu lintas dan angkutan jalan, diatur tentang pengutamaan petugas yaitu dalam keadaan tertentu untuk ketertiban dan kelancaran lalu lintas dan angkutan jalan, petugas kepolisian negara republik indonesia dapat melakukan tindakan:

a. memberhentikan arus Lalu Lintas dan/atau Pengguna Jalan;

\footnotetext{
25 Ifadhloh, Nihayatul. (2014, Desember 3). Hubungan Hukum dan Keadilan. Diakses pada tanggal Maret 6, 2017. Neha Iefaza: http://nihayatulifadhloh.blogspot.co.id/2014/12/hubungan-hukum-dan-keadilan.html.

26 Dede, Win. (2006, Februari 17). Komplotan Moge, Apa Kalian Asosial?. Diakses pada tanggal 2017, Januari 17. Win: http://windede.com/2006/02/17/komplotan-moge-apa-kalian-asosial.
} 
b. memerintahkan Pengguna Jalan kekuasaan kepada anak-anak atau orang tidak untuk jalan terus;

c. mempercepat arus Lalu Lintas;

d. memperlambat arus Lalu Lintas; dan/atau

e. mengalihkan arah arus Lalu Lintas.

Selanjutnya di ayat dua (2) disebutkan tindakan sebagaimana dimaksud pada ayat (1) wajib diutamakan daripada perintah yang diberikan oleh alat pemberi isyarat lalu lintas, rambu lalu lintas, dan/atau marka jalan. Dan ayat tiga (3) pengguna Jalan wajib mematuhi perintah yang diberikan oleh petugas Kepolisian Negara Republik Indonesia sebagaimana dimaksud pada ayat (1). Sekilas mungkin kita pernah berpikir bahwa orangorang yang mendapatkan pengawalan dari kepolisian adalah orang-orang VIP (Very Important Person). Namun dalam peraturan perundang-undangan terutama di bidang lalu lintas, tidak dikenal istilah pengguna jalan VIP (Very Important Person). Tetapi istilah yang diatur dalam peraturan perundangundangan adalah "pengguna jalan yang diprioritaskan" atau "kendaraan bermotor yang memiliki hak utama". ${ }^{27}$

Penilaian keadilan atau ketidakadilan hukum bisa jadi dihadapkan pada pendapat berlawanan yang dituntun oleh sebuah moralitas yang berbeda. Misalnya hukum yang mengecualikan atau tidak memberikan sehat akalnya dalam pembuatan kontrak atau wasiat dianggap adil. Karena mereka tidak memiliki kapasitas, yang dimiliki oleh orang dewasa yang sehat akalnya. Diskriminasi ini dibuat atas alasan yang jelas-jelas relevan. ${ }^{28}$ Terkait dengan undang-undang bahwa undang-undang dibuat dengan tujuan kebaikan masyarakat, keamanan rakyat, perdamaian dan keadilan. Oleh karena itu para pembuat undang-undang harus merumuskan dan menuliskan sesuai dengan moral dan kebahagiaan umum sehingga rakyat menerima dan mentaati, yang didalamnya tercakup seluruh hakikat dan seluruh daya keadilan. ${ }^{29}$

Dalam Pasal 134 diatur bahwa pengguna Jalan yang memperoleh hak utama untuk didahulukan sesuai dengan urutan berikut:

a. Kendaraan pemadam kebakaran yang sedang melaksanakan tugas;

b. Ambulans yang mengangkut orang sakit;

c. Kendaraan untuk memberikan pertolongan pada Kecelakaan Lalu Lintas;

d. Kendaraan pimpinan Lembaga Negara Republik Indonesia;

e. Kendaraan pimpinan dan pejabat negara asing serta lembaga internasional yang menjadi tamu negara;

f. Iring-iringan pengantar jenazah; dan

g. Konvoi dan/atau Kendaraan untuk kepentingan tertentu menurut pertimbangan petugas Kepolisian

\footnotetext{
27 Hadi, Ilman. Pengaturan Lalu Lintas Bagi Penggunaan Jalan yang Diprioritaskan. Diakses pada tanggal Januari 17, 2017. Hukum Online: http://www.hukumonline.com/klinik/detail/lt4fe3f8042e887/pengaturanlalu-lintas-bagi-pengguna-jalan-yang-diprioritaskan

28 Petrus, Bello. (2012). Hukum dan Moralitas. Jakarta: Erlangga. Hlm. 39

29 Rasjidi, Lili. (1994). Filsafat Hukum Mazhab dan Refleksinya. Bandung: Remaja Rosdakarya Offset. Hlm. 27
} 
Negara Republik Indonesia.

Khusus pada point $\mathrm{g}$ di dalam penjelasaannya, yang dimaksud dengan "kepentingan tertentu" adalah kepentingan yang memerlukan penanganan segera, antara lain kendaraan untuk penanganan ancaman bom, kendaraan pengangkut pasukan, kendaraan untuk penanganan huru-hara, dan kendaraan untuk penanganan bencana alam.

Apabila kita melihat peraturan perundangundangan tersebut beserta penjelasannya maka iring-iringan untuk mobil plat hitam atau club-club mobil atau motor tidak diperbolehkan menggunakan voorijder, meskipun dalam point $\mathrm{g}$ disebutkan konvoi tetapi jelas konvoi mobil atau motor plat hitam tersebut tidak masuk dalam kategori kepentingan tertentu.

Lahirnya Undang-Undang No 22 Tahun 2009 tentang Lalu Lintas dan Angkutan Jalan merupakan pengimplikasian dari tujuan hukum. Dimana dalam menegakkan hukum ada tiga unsur yang harus diperhatikan, yaitu: kepastian hukum, kemanfaatan dan keadilan. Ketiga unsur tersebut harus ada kompromi, harus mendapat perhatian secara proporsional seimbang. Tetapi dalam praktek tidak selalu mudah mengusahakan kompromi secara proporsional seimbang antara ketiga unsur tersebut. Tanpa kepastian hukum orang tidak tahu apa yang harus diperbuatnya dan akhirnya timbul keresahan. Tetapi terlalu menitikberatkan pada kepastian hukum, terlalu ketat mentaati peraturan hukum akibatnya kaku dan akan menimbulkan rasa tidak adil.

Adanya kepastian hukum merupakan harapan bagi pencari keadilan terhadap tindakan sewenang-wenang dari aparat penegak hukum yang terkadang selalu arogansi dalam menjalankan tugasnya sebagai penegak hukum. Karena dengan adanya kepastian hukum masyarakat akan tahu kejelasan akan hak dan kewajiban menurut hukum. Tanpa ada kepastian hukum maka orang akan tidak tahu apa yang harus diperbuat, tidak mengetahui perbuatanya benar atau salah, dilarang atau tidak dilarang oleh hukum.

Kepastian hukum ini dapat diwujudkan melalui penoramaan yang baik dan jelas dalam suatu undang-undang dan akan jelas pulah penerapanya. Dengan kata lain kepastian hukum itu berarti tepat hukumnya, subjeknya dan objeknya serta ancaman hukumanya. Akan tetapi kepastian hukum mungkin sebaiknya tidak dianggap sebagai elemen yang mutlak ada setiap saat, tapi sarana yang digunakan sesuai dengan situasi dan kondisi dengan memperhatikan asas manfaat dan efisiensi. ${ }^{30}$

Keadilan di indonesia digambarkan dalam

30 Dungge, Rasjudiin. (2013, Juni 18). Hubungan Tiga Tujuan Hukum: Kepastian Hukum, Kemanfaatan dan Keadilan. Diakses pada tanggal Januari 24, 2017. Rasjuddin Dungge: http://rasjuddin.blogspot.co.id/2013/06/hubungan-3-tujuan-hukum-kepastian-hukum.html. 
Pancasila sebagai dasar negara, yaitu keadilan sosial bagi seluruh rakyat Indonesia. Nilainilai yang terkandung dalam sila keadilan sosial bagi seluruh rakyat Indonesia didasari dan jiwai oleh sila Ketuhanan Yang Maha Esa, Kemanusian yang Adil dan Beradab, Persatuan Indonesia, serta Kerakyatan yang Dipimpin oleh Hikmat Kebijaksanaan dalam Permusyawaratan perwakilan. ${ }^{31}$

Nilai-nilai keadilan tersebut haruslah merupakan dasar yang harus diwujudkan dalam hidup bersama bernegara untuk mewujudkan tujuan negara, yaitu mewujudkan kesejahteraan sekuruh warga dan seluruh wilayah, mencerdaskan seluruh warganya. ${ }^{32}$ Keadilan sosial berarti keadilan yang berlaku dalam masyarakat di segala bidang kehidupan salah satunya adalah keadilan dalam menggunakan fasilitas negara dalam bentuk jalan raya. Dalam Pasal 134 Undang-Undang No 22 tahun 2009 diatur bahwa pengguna Jalan yang memperoleh hak utamalah yang harus didahulukan, menurut penulis udah mencerminkan rasa keadilan karena mereka ini harus mendapatkan prioritas saat menjalankan tugasnya. Yang mana terkadang dalam menjalanan tugasnya mungkin sedang memburu waktu dan fakta di jalan raya kita tahu di indonesia banyak sekali kendaraan bermotor yang sering menyebabkan kemancetan, maka sudah selayaknya mereka mendapatkan pengawalan voorijder untuk mendapatkan jalan.

Berbicara tujuan hukum dalam UndangUndang No 22 Tahun 2009 juga dipengaruhi dengan sistem hukum menurut Lawrence Friedman yaitu efektif dan berhasil tidaknya penegakan hukum tergantung tiga unsur sistem hukum, yakni struktur hukum (struktur of law), substansi hukum (substance of the law) dan budaya hukum (legal culture). Struktur hukum menyangkut aparat penegak hukum, substansi hukum meliputi perangkat perundang-undangan dan budaya hukum merupakan hukum yang hidup (living law) yang dianut dalam suatu masyarakat. ${ }^{33}$

Struktur Hukum/Pranata Hukum dalam teori Lawrence Meir Friedman hal ini disebut sebagai sistem Struktural yang menentukan bisa atau tidaknya hukum itu dilaksanakan dengan baik. Struktur hukum berdasarkan UU No. 8 Tahun 1981 meliputi mulai dari Kepolisian, Kejaksaan, Pengadilan dan Badan Pelaksana Pidana (Lapas). Kewenangan lembaga penegak hukum dijamin oleh undang-undang. Sehingga dalam melaksanakan tugas dan tanggung jawabnya terlepas dari pengaruh kekuasaan pemerintah dan pengaruh-pengaruh lain. Hukum tidak dapat berjalan atau tegak bila tidak ada aparat

31 Santoso, Agus. (2012). Hukum Moral dan Keadilan. Jakarta: Kencana Prenada Media Group. Hlm. 87.

32 Kaelan. (2007). Pendidikan Kewarganegaraan untuk Perguruan Tinggi. Yogyakarta: Paradigma. Hlm. 36

33 Andreas, D. (2015, Maret 28). Teori Sistem Hukum Lawrence M. Friedman. Diakses pada Januari, $25,2017$. Dari Dede Andreas :http://dedeandreas.blogspot.co.id/2015/03/teori-sistem-hukum-lawrence-mfriedman.html. 
penegak hukum yang kredibilitas, kompeten dan independen.

Masalah yang ditimbulkan dari struktur hukum yaitu banyak kasus penyelewengan kewenangan di ranah penegak hukum kepolisian yang banyak melakukan pelanggaran, contoh salah satunya dengan memberikan pengawalan kepada mobil atau motor plat hitam yang jelas-jelas tidak termasuk dalam pasal 134 Undang-Undang No 22 Tahun 2009 Tentang Lalu Lintas dan Angkutan Jalan. Padahal apabila kita melihat aspek lain dari sistem hukum adalah substansinya. Dimana yang dimaksud dengan substansi adalah aturan, norma, dan pola perilaku nyata manusia yang berada dalam sistem itu. Maka jelas sudah diatur kendaraan apa saja yang mendapat prioritas di jalan raya, sehingga substansi hukum menyangkut peraturan perundang-undangan yang berlaku yang memiliki kekuatan yang mengikat dan menjadi pedoman bagi aparat penegak hukum. Dan terakhir Kultur hukum menyangkut budaya hukum yang merupakan sikap manusia (termasuk budaya hukum aparat penegak hukumnya) terhadap hukum dan sistem hukum. Sebaik apapun penataan struktur hukum untuk menjalankan aturan hukum yang ditetapkan dan sebaik apapun kualitas substansi hukum yang dibuat tanpa didukung budaya hukum oleh orang-orang yang terlibat dalam sistem dan masyarakat maka penegakan hukum tidak akan berjalan secara efektif. ${ }^{34}$

\section{DAFTAR PUSTAKA}

\section{Buku}

Asshiddiqie, Jimly dan Safaat, Ali. (2012). Teori Hans Kelsen Tentang Hukum. Jakarta: Konpres.

Erwin, Muhammad. (2011). Filsafat Hukum Refleksi Kritis Terhadap Hukum. Jakarta: Sinar Grafika.

Hay, Marhainis Abdul. (1981). Dasar-dasar Ilmu Hukum. Jakarta: Pradnya Paramita.

Huijbers, Theo. (1995). Filsafat Hukum Dalam Lintas Sejarah. Yogyakarta: Kanisius.

Huijbers, Theo. Filsafat Hukum. Yogyakarta: Kanisius.

Kaelan. (2007). Pendidikan Kewarganegaraan untuk Perguruan Tinggi. Yogyakarta: Paradigma.

Lili Rasjidi. (2007). Pengantar Filsafat Hukum. Bandung: Mandar Maju.

Mas, Marwan. (2014). Pengantar Ilmu Hukum. Bogor: Ghalia Indonesia.

Muchsin. (2006). Ikhtisar Ilmu Hukum Jakarta: Badan Penerbit IBLAM.

Rahardjo, Satjipto. (2000). Ilmu Hukum. Bandung: PT Citra Aditya Bakti.

Jagat Ketertiban. Jakarta: UKI Press.

Raper, Jan Hendrik. (1991). Politik Hukum Plato. Jakarta: Rajawali. 1991.

34 Umah, K. (2016, Maret 26). Sistem Hukum Menurut Lawrence M Friedman. Diakses pada Januari 25, 2017. Dari Khoiru Umah:http://khoiruumah96.blogspot.co.id/2016/03/normal-0-false-false-false-en-us-X-none.html 
Rasjidi, Lili dan Rasjidi, Ira. Thania. (2012). Pengantar Filsafat Hukum. Bandung: Mandar Maju.

Rasjidi, Lili. (1994). Filsafat Hukum Mazhab dan Refleksinya. Bandung: Remaja Rosdakarya Offset.

Santoso, Agus. (2012). Hukum Moral dan Keadilan. Jakarta: Kencana Prenada Media Group.

Santoso, Agus. (2012). Hukum Moral dan Keadilan. Jakarta: Kencana Prenada Media Group.

Suseno, Franz Magnis. (1999). Etika Politik (Prinsip-prinsip Moral Dasar Kenegaraan Modern). Jakarta: PT Gramedia Pustaka Utama.

Tulisan Bersama. (2014). Anotasi Pemikiran Hukum Dalam Perspektif Filsafat Hukum. Malang: UB Press.

Zainuddin, Ali. (2010). Filsafat Hukum. Jakarta: Sinar Grafika.

\section{Peraturan Perundang-undangan}

Undang-Undang No 22 Tahun 2009 tentang Lalu Lintas dan Angkutan Jalan

Peraturan Kepala Kepolisian Negara Republik Indonesia No. 5 Tahun 2012 tentang Registrasi dan Identifikasi Kendaraan Bermotor

\section{Internet}

(2010, Juli 9). Pengawalan Kendaraan oleh Polisi Siapa Saja yang Berhak. Diakses pada tanggal Januari 20, 2017.Nomed: https://noem3d.wordpress.com/2009/06/1 1/pengawalan-kendaraan-oleh-polisisiapa-saja-yang-berhak.

Ajim, Nanang. Huubungan Hukum, Keadilan, dan Ketertiban. Diakses pada tanggal Maret 6, 2017. Mikirbae: http://www.mikirbae.com/2015/11/hubun gan-hukum-keadilan-dan-ketertiban.html.

Andreas, D. (2015, Maret 28). Teori Sistem Hukum Lawrence M. Friedman. Diakses pada Januari, 25, 2017. Dari Dede Andreas :http://dedeandreas.blogspot.co.id/2015/03 /teori-sistem-hukum-lawrence-mfriedman.html.

CR, Miftah. (2014, Januari 11). Hak dan Kewajiban Warga Negara dalam Berlalu Lintas. Diakses pada Januari 16, 2017. MiftahC.R.:http://learnmcr.blogspot.co.id/ 2014/01/hak-dan-kewajiban-warganegara-dalam_7139.html.

Dede, Win. (2006, Februari 17). Komplotan Moge, Apa Kalian Asosial?. Diakses pada tanggal 2017, Januari 17. Win: http://windede.com/2006/02/17/komplota n-moge-apa-kalian-asosial.

Dungge, Rasjudiin. (2013, Juni 18). Hubungan Tiga Tujuan Hukum: Kepastian Hukum, Kemanfaatan dan Keadilan. Diakses pada tanggal Januari 24, 2017. Rasjuddin Dungge: http://rasjuddin.blogspot.co.id/2013/06/hu bungan-3-tujuan-hukum-kepastianhukum.html.

Hadi, Ilman. Pengaturan Lalu Lintas Bagi Penggunaan Jalan yang Diprioritaskan. Diakses pada tanggal Januari 17, 2017. Hukum Online: http://www.hukumonline.com/klinik/detai 1/lt4fe3f8042e887/pengaturan-lalu-lintasbagi-pengguna-jalan-yang-diprioritaskan.

Ifadhloh, Nihayatul. (2014, Desember 3). Hubungan Hukum dan Keadilan. Diakses pada tanggal Maret 6, 2017. Neha Iefaza: http://nihayatulifadhloh.blogspot.co.id/20 14/12/hubungan-hukum-dankeadilan.html.

Umah, K. (2016, Maret 26). Sistem Hukum Menurut Lawrence M Friedman. Diakses pada Januari 25, 2017. Dari Khoiru Umah 
34 Yurispruden Volume 1, Nomor 2 , Januari 2018, Halaman 17-34

:http://khoiruumah96.blogspot.co.id/2016/

03/normal-0-false-false-false-en-us-X-

none.html. 